Article

\title{
Sensitivity of stomate size in red maple (Acer rubrum L.) trees in deciduous forests to urban conditions.
}

\author{
Covel R. McDermot ${ }^{1, *}$, Vince $\mathrm{D}^{\prime}$ Amico $^{2}$ and Tara Trammell $^{1}$ \\ 1 Department of Plant and Soil Sciences, University of Delaware, Newark, DE, 19716 \\ 2 USDA Forest Service, Northern Research Station, NRS-08, Newark, DE, 19716 \\ * Correspondence: skalla@udel.edu (CM)
}

\begin{abstract}
Environmental conditions, such as temperature, carbon dioxide, and nutrient availability, are altered by urban conditions at regional scales with potential for impact on tree leaf structure. Our goal was to compare leaf morphological characteristics driven by physiological acclimation in red maple (Acer rubrum L.) trees in deciduous forests embedded in a small (Newark, DE) and a large (Philadelphia, PA) city. The study was conducted in six urban forests on eighteen mature red maple trees in a long-term urban forest network. We hypothesized that red maples in Philadelphia forests compared to Newark forests will have a thicker upper epidermal layer, spongy palisade and mesophyll layer, longer and wider stomates, and lower stomate density. Additionally, we hypothesized that red maples in Philadelphia forests compared to Newark forests will have lower leaf water content and specific leaf area, and greater leaf thickness, fresh leaf weight, dry leaf weight, and leaf dry matter content. Our results for stomate length and stomate width supported our predictions; red maple leaves had longer and wider stomates in Philadelphia forests than in Newark forests. The increased stomate size in red maple trees suggests potential altered gas exchange behavior and mutual abiotic stress mitigation responses in red maple to greater urbanization impacts in Philadelphia forests. This supports previous findings of possible physiological and biochemical acclimation of red maple trees to urban conditions. Furthermore, the findings from this study suggest red maple trees may be a good biomonitor of regional scale impacts in urban environments.
\end{abstract}

Keywords: Abiotic stress; metro-scale; physiological acclimation; urban leaf morphology; red maple trees; stomate size; urban forests

\section{Introduction}

Environmental conditions across cities are influenced by different magnitudes of urbanization impacts that can alter leaf structure, which has global implications for urban forest health as trends of urbanization and human population density increase. Cities can be excellent surrogates in assessments of the combined impacts of global change on plants [1], and leaves can be a good biomonitor of local site conditions and regional scale impacts [2,3]. Urban forest trees are impacted by higher temperatures (urban heat island, UHI; [4]), increased atmospheric CO2 concentrations [5,6], greater reactive $\mathrm{N}$ deposition inputs [7], higher soil nutrient loads, and greater soil heavy metal contamination [8] compared to their rural counterparts. The byproducts of urbanization, such as heat, nutrients, and heavy metals, can alter the anatomy and morphology of leaves [9-11], yet little is known about how urbanization impacts combined will influence leaf morpho-anatomy traits in urban forests. Foliar morpho-anatomy responses to varying degrees of urbanization can provide valuable insight into tree carbon sink capacity, air pollution mitigation, and tree health in urban environment. 
Forests and trees have the potential to improve environment quality in urban areas through blockage, uptake, and immobilization of pollutants [12,13]. Plant leaves have the ability to trap, sequester, and compartmentalize pollutants [14,15]. Urban forest trees may also provide important benefits through pollution regulation of urban conditions. However, this is debatable due to biogenic volatile organic compound (BVOC) production by urban trees [16 ], and for some pollutants, like particulates, the aerodynamic effect of tree canopies can influence particulate residence time, recirculation, and concentration in urban environments [17,18]. Alternatively, urban air pollutants can affect tree growth and function; tropospheric ozone has been reported to induce visible injuries, de-regulate stomatal conductance, and reduce photosynthesis and leaf area $[19,20]$. These complex interactions with urban tree canopies and atmospheric pollutants may stress trees, leading to shorter lifespan even with enhanced growth rates [21]. Thus, the ability of urban trees to mitigate urban conditions and improve environment quality and sustainability of cities may be dampened by their response to altered urban environmental conditions [17,22,23].

The morphological and anatomical traits in leaves can serve as a bioindicator of plant response to altered environmental conditions, specifically air $[15,24]$ and soil $[2,25,26]$ pollution. Trees exposed to auto-exhaust pollution exhibited leaf structural changes (e.g., increased stomatal density, trichome length, collapsed epidermal cell), yet no differences in leaf phenology [24]. Leaf size and stomate density were reduced in London plane trees in a highly urbanized environment compared to a rural area; however, area of palisade parenchyma cells and spongy parenchyma cells were unchanged with urbanization [11]. In many disturbed ecosystems and experimental studies, reports of dryer or wetter soils [2,27], soil contaminant enrichment [28], and altered soil biogeochemistry [29] seem to result in contrasting plant response traits $[11,19,20,24,30,31]$. Tree species that display morpho-anatomical responses and physiological acclimation to abiotic stressors in contrasting environmental impacts can provide more insights into multiple cumulative impacts on urban trees. In urban environments, red maple trees exhibit enhanced productivity [32] and increased concentration of secondary metabolites [3], which suggests red maple trees physiologically acclimate to urban conditions, yet little is known about red maple morphological and anatomical responses to urbanization.

Since the turn of the late twentieth century, red maple (Acer rubrum) trees have dominated a wide range of ecological biomes, particularly forest stands in the northeastern to southeastern United States [2,33,34]. The morphology and growth characteristics of red maple in forest stands in the eastern U.S. have resulted in wide scale cultivation because of its aesthetics, marketability, and adaptability in many urban landscapes [33-35]. Importantly, red maple trees are a dominant tree across urban forests [36] and demonstrate healthy growth and function despite potentially harsh environmental conditions in cities $[3,32]$.

The purpose of this study was to determine changes in red maple leaf morphology and anatomy in response to urban conditions. To understand the combined impacts of different magnitudes of urban intensity (i.e., large versus small city; hereafter metro-scale impacts) on leaf anatomy and morphology, we investigated red maple trees in forests embedded in two cities (i.e., Newark, DE and Philadelphia, PA). These cities differ in total population, developed land area, and impervious surface cover. This research utilized a long-term urban forest ecology network, the FRAME, to study how red maple leaves respond to combined metro-scale impacts in a small city (Newark, DE) and a large city (Philadelphia, PA). We measured leaf morphology traits (i.e., fresh leaf weight, dry leaf weight, specific leaf area, leaf thickness, leaf dry matter content, and leaf water content) and anatomy traits (i.e., upper epidermal thickness, palisade mesophyll thickness, spongy mesophyll thickness, stomata density, stomate length, and stomate width). We asked the following questions: 1) Do red maple trees exhibit differing leaf morphology in response to combined metro-scale impacts? 2) Do red maple trees exhibit differing leaf anatomy in response to metro-scale impacts? and 3) Are there morpho-anatomy patterns that indicate plasticity of trees to metro-scale impacts? We hypothesized that red maples in Philadelphia forests will have greater fresh leaf weight, dry leaf weight, leaf dry matter content, leaf thickness, upper epidermal thickness, palisade mesophyll length, stomatal density, stomatal length, and stomatal width compared to red maples in Newark forests due to increased protection against altered biogeochemistry and elevated temperatures, nutrients, and 
contaminants $[10,11,15,24,26,30]$. In addition, lower leaf water content, specific leaf area, and spongy mesophyll length are expected in trees from Philadelphia forests compared to Newark forests due to the urban heat island. We expect warmer temperatures, increased atmospheric $\mathrm{CO} 2$ concentrations, and greater nutrient deposition inputs in Philadelphia forests will result in altered leaf morphoanatomy and plasticity that support the physiological acclimation of red maple trees to these urban conditions [3].

\section{Results}

\subsection{Leaf morphology traits}

In general, leaf morphology traits of red maple trees were similar between Newark and Philadelphia forests. We found no significant differences in fresh leaf weight, dry leaf weight, dry leaf area, specific leaf area, or leaf dry matter content of red maple trees in Newark and Philadelphia forests (Table 1). However, we found a significant trend in red maple leaf water content (LWC); red maple trees in Newark forests had slightly higher LWC (\%) compared to red maple trees in Philadelphia forests $(\mathrm{p}=0.06$; Table 1$)$.

Table 1. Leaf morphology traits for red maple trees in six forests in Newark, DE and Philadelphia, PA.

\begin{tabular}{ccc}
\hline Morphology trait & Newark forests & Philadelphia forests \\
\hline FLW $(\mathrm{g})$ & $4.9 \pm 0.4^{\text {n.s. }}$ & $5.3 \pm 0.5^{\text {n.s. }}$ \\
DLW $(\mathrm{g} \mathrm{DW})$ & $2.2 \pm 0.2^{\text {n.s. }}$ & $2.6 \pm 0.2^{\text {n.s. }}$ \\
LA $\left(\mathrm{cm}^{2}\right)$ & $46.6 \pm 4.1^{\text {n.s. }}$ & $52.8 \pm 3.1^{\text {n.s. }}$ \\
SLA $\left(\mathrm{cm}^{2} \mathrm{~g}^{-1} \mathrm{DW}\right)$ & $21.0 \pm 0.9^{\text {n.s. }}$ & $20.5 \pm 0.8^{\text {n.s. }}$ \\
LDMC $\left(\mathrm{g} \mathrm{g}^{-1}\right)$ & $0.5 \pm 0.02^{\text {n.s. }}$ & $0.5 \pm 0.01^{\text {n.s. }}$ \\
LWC $(\%)$ & $\mathbf{5 4 . 6} \pm \mathbf{1 . 8}^{*}$ & $50.1 \pm 1.2$ \\
\hline
\end{tabular}

Values are morphology measurements of leaves $(n=10)$ per tree for 18 trees (mean \pm SE)

FLW: fresh leaf weight

DLW: dry leaf weight

DLA: dry leaf area

SLA: specific leaf area

LDMC: leaf dry matter content

LWC: leaf water content

*represents significant differences between means when $\alpha \leq 0.10$

n.s. represents no significant differences between means

\subsection{Leaf anatomy traits}

Comparable to leaf morphology traits, leaf anatomy traits in red maple trees were similar between Newark and Philadelphia forests (Figure 1). There were no significant differences in internal leaf anatomy traits, specifically leaf thickness, upper epidermal thickness, spongy mesophyll length, and spongy palisade length in red maple trees growing in Philadelphia and Newark forests $(p>0.10$; Figure 2). Similarly, on the leaf abaxial surface, there were no differences in stomatal density of red maple trees in Philadelphia or Newark forests ( $p>0.10$; Figure 3). However, we found differences in leaf stomate size between the two cities. The leaf stomate length (SL) and width (SW) were significantly greater in red maple trees in Philadelphia forests (SL: 9.6 $\pm 0.2 \mu \mathrm{m}$; SW: $15.8 \pm 0.3 \mu \mathrm{m}$ ) compared to red maple trees in Newark forests (SL: $8.9 \pm 0.4 \mu \mathrm{m}$; SW: $14.8 \pm 0.8 \mu \mathrm{m} ; \mathrm{p}<0.10$; Figure 2). 

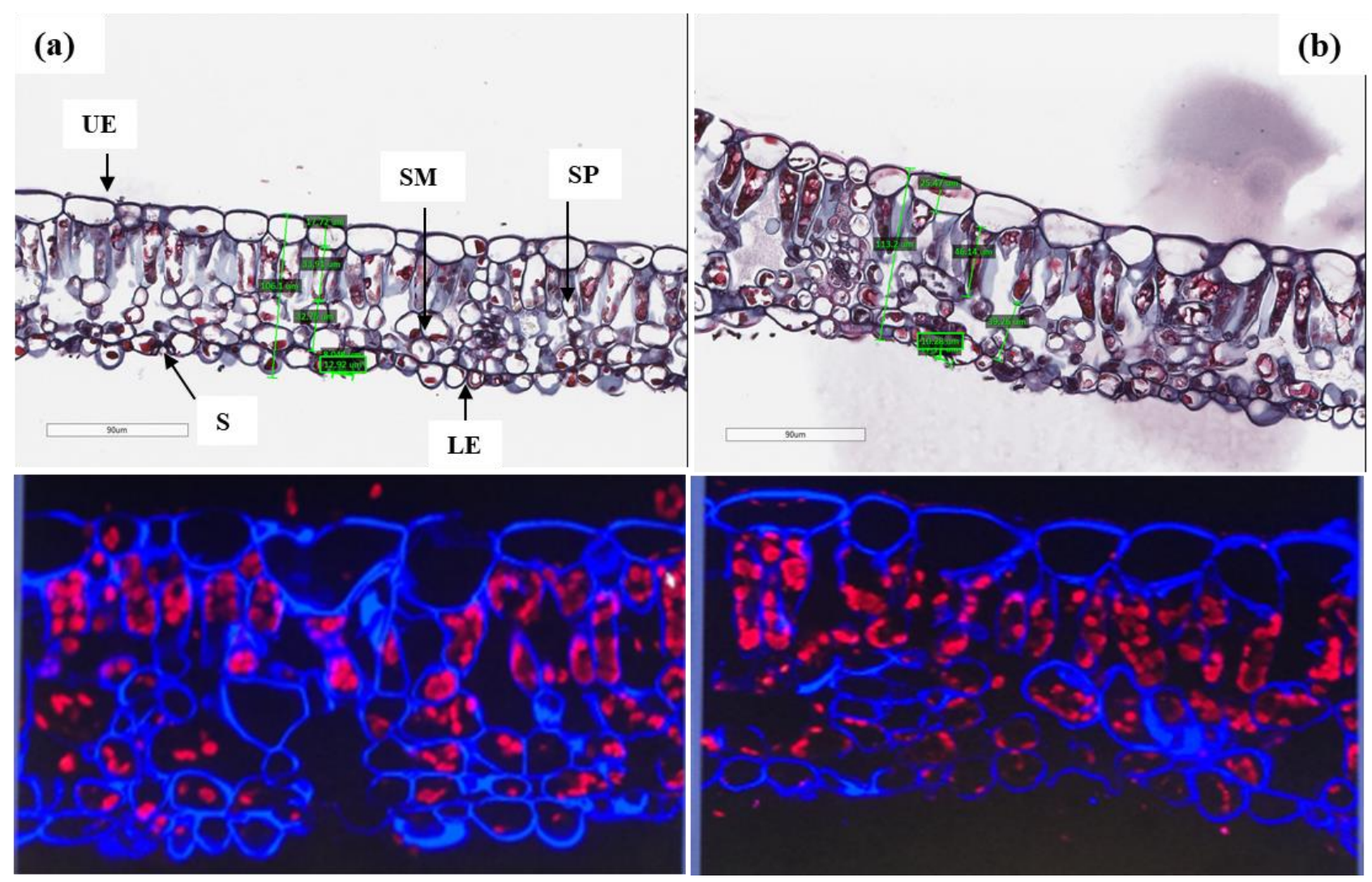

Figure 1. Cross sectional view $(90 \mu \mathrm{m})$ of internal (anatomical) leaf structures of red maple trees in Newark (a) and Philadelphia (b) forests. UE: Upper epidermis; S: Stomate; SM: Spongy mesophyll; SP: Spongy palisade; LE: Lower epidermis. 

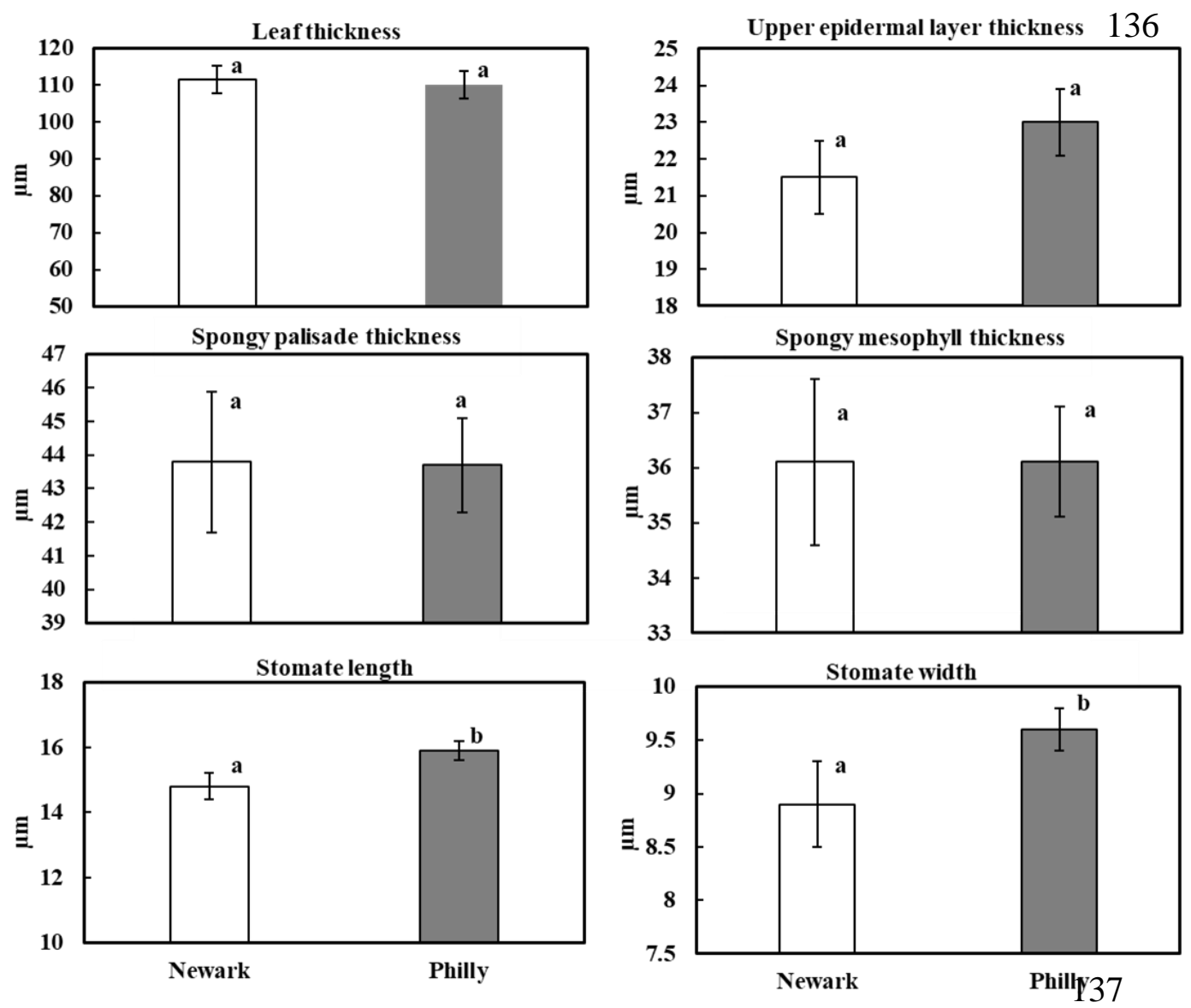

Figure 2. Leaf anatomy traits of red maple trees in Newark and Philadelphia forests. Letters represent significant differences between means when $\alpha \leq 0.10$. 

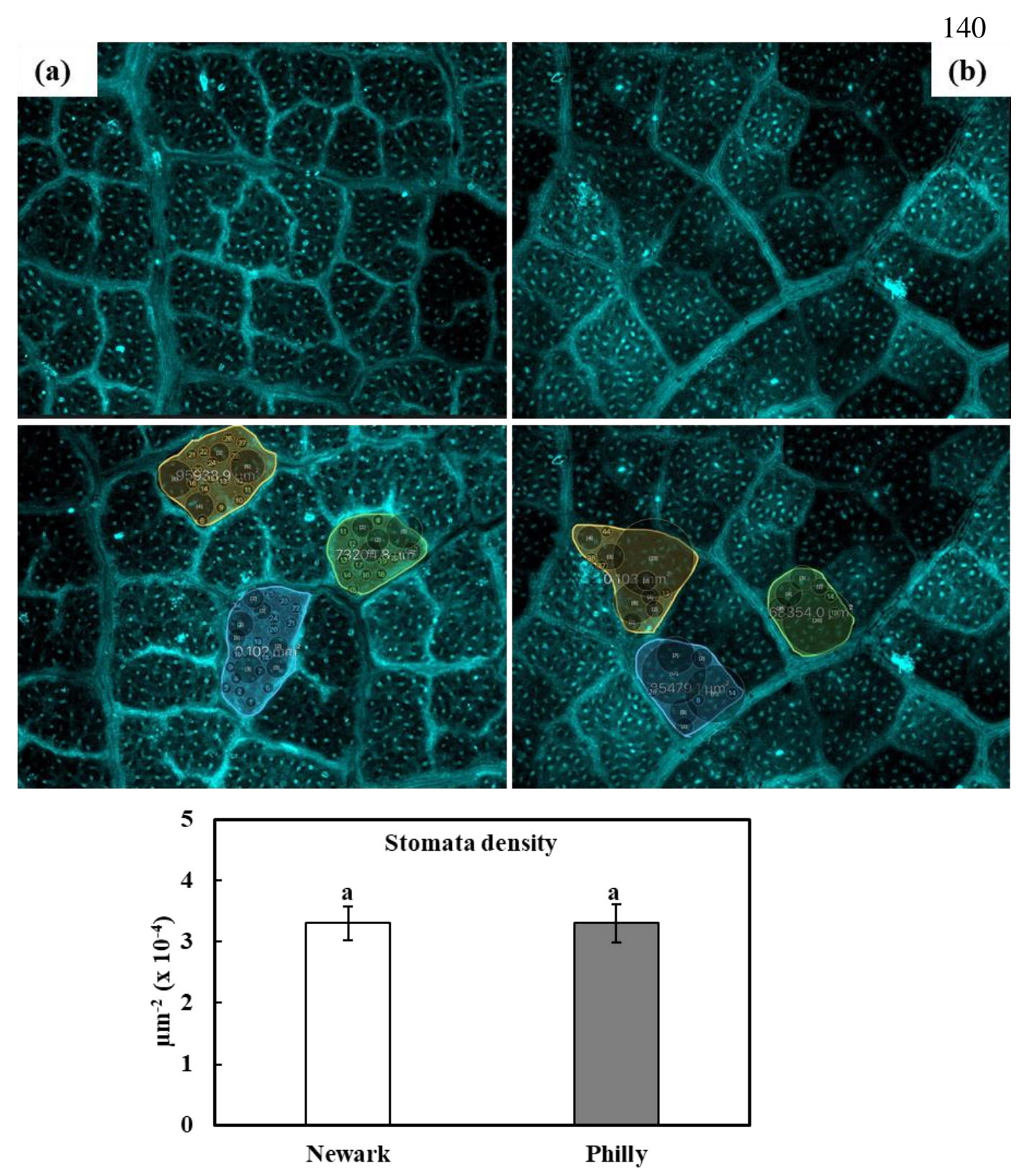

Figure 3. Stomata density of the leaf abaxial surface of red maple trees in Newark (a) and Philadelphia (b) forests. Letters represent significant differences between means when $\alpha \leq 0.1$.

\section{Discussion}

This study demonstrates the robust nature of red maple tree morphology and anatomy in urbanized settings. Foliar morphology and internal anatomy were similar in red maple trees growing in Philadelphia and Newark forests. However, we did find red maple trees in Philadelphia forests had greater stomate size and lower leaf water content compared to Newark forests. The increase in stomate length and width (i.e., larger guard cells) of red maple trees growing in Philadelphia forests suggests the stomates potentially have lower stomatal conductance rates and/or slower response times (i.e., stomatal kinetics) to urban conditions. Furthermore, the trend for lower leaf water content in red maple trees in Philadelphia forests compared to Newark forests suggests possible acclimation to water limited systems and/or greater transpiration (i.e., more water loss) as a result of slower stomatal response time with larger stomata [37].

Environmental conditions, such as elevated atmospheric $\mathrm{CO} 2$ and warmer temperatures, have the potential to drive changes in stomatal conductance and stomatal kinetics [38-41]. Miller-Rushing et al. [10] have found increased guard cell length and decreased stomate density in response to higher 
temperatures $\left(1.8^{\circ} \mathrm{C}\right)$ independent of global $\mathrm{CO} 2$ rise $(>86 \mathrm{ppm})$ over a 100-year period, and intrinsic water use efficiency (iWUE) remained unchanged. While we did not observe differences in stomatal density in red maple trees in forests of differing city sizes, the trend for increased stomate size (i.e., guard cell length and width) in the large city (Philadelphia, PA) suggests some level of stomate plasticity as a result of acclimation to elevated light, $\mathrm{CO} 2$ and/or temperature [37,42]. Furthermore, red maple trees in urban forests appear to respond to elevated temperature and light via regulatory changes in stomate size and possibly iWUE rather than increased stomatal density [10,37,42]. In contrast to findings reported by Drake et al. [37], leaves of red maple trees in forests in Philadelphia likely acclimated to higher rates of gas exchange through slower dynamic characteristics of larger stomata to abiotic stress by slowly opening stomate pores (stomatal conductance). This would increase evapotranspiration losses under elevated $\mathrm{CO} 2$ conditions by maximizing $\mathrm{CO} 2$ uptake and enhance growth rates. The slightly lower leaf water content in red maples in Philadelphia forests, coupled with greater growth [32], and increased concentration of secondary metabolites [3] are likely achieved from higher iWUE $[37,39,40,42]$. These findings of increased stomate length and stomate width (and unchanged stomatal density) and many unaffected morpho-anatomical traits further support the robust genetic background and plasticity through epigenetics of red maple trees to greater magnitudes of urban intensity.

In conjunction with stomatal size, foliar nutrient concentrations can indicate potential stomatal conductance behavior and/or kinetics. Wang et al. [43] and Egilla et al. [44] found that lower leaf water content was linked to lower potassium levels, which directly regulate stomatal conductance and root depth (along with $\mathrm{N}$ and $\mathrm{P}$ ). However, we found higher foliar $\mathrm{K}+[3]$ in red maple trees with lower leaf water content, which may be due to acclimation to drier urban conditions. Higher foliar $\mathrm{K}+$ ions may play a role in signaling accumulation of polyamines, amino acids, and solutes that may aid in osmotic adjustment and increase the intrinsic water-use efficiency (iWUE) of the trees. Therefore, lower leaf water content and increased cellular free signaling ions along with reported elevated free metabolites [3] in red maple trees in Philadelphia forests are likely main players regulating intrinsic water-use efficiency and osmotic adjustment for lower leaf water content when $\mathrm{K}+$ ions are preferentially taken up and accumulate in cells.

Leaf water content changes within tree species are linked to iWUE and may be a complex subcellular communication response to stomatal conductance and stomatal kinetics that signal osmoregulatory processes to bring about cellular osmotic adjustment to altered environmental cues [42]. Many studies have reported the positive effects of cytosolic free $\mathrm{K}+, \mathrm{Ca} 2+, \mathrm{Zn} 2+$ and $\mathrm{N}$ containing compounds on low leaf water content and cellular osmoregulation through mechanisms that control reactive oxygen species (ROS) levels, improve membrane integrity, and regulate cellular osmotic adjustment and stomatal responsiveness, thus improving plant tolerance to multiple abiotic (and biotic) stresses [37,43-46]. McDermot et al. [3] found increased foliar N, K, P, Zn, chlorophyll, proline, glutamine, arginine, and spermine in red maple trees growing in high nutrient and heavy metal soils in Philadelphia forests. Interestingly, $\mathrm{K}$ and $\mathrm{Zn}$ were tightly correlated to free amino acids in trees experiencing greater urban intensity. This suggests these nutrients likely communicate with $\mathrm{N}$-containing metabolites to play a role in cellular osmotic adjustment response and ROS detoxification to oxidative stress induced by heavy/toxic metals (e.g., $\mathrm{Mn}, \mathrm{Al}, \mathrm{Zn}$ ) and/or salinity stress in these red maple trees. Furthermore, altered cellular $\mathrm{K}+/ \mathrm{Na}+$ homeostasis can induce cellular desiccation (i.e., lower cell water content) and signal an osmotic stress response that triggers the regulation of water and nutrient balance, regulation of iWUE, and cellular osmotic adjustment [26,4648]. Interestingly, McDermot et al. [3] found increased foliar $\mathrm{Mg}$, very toxic levels of $\mathrm{Mn}$, and lower chlorophyll and proline in red maple trees growing in low soil $\mathrm{pH}$ and low soil organic matter in Newark forests compared to Philadelphia forests. These findings suggest faster stomatal kinetics in response to more disturbed, nutrient-limited (e.g., P, K) soils and foliar Mn-induced oxidative stress (chlorophyll degradation in chloroplasts) under excess soil moisture conditions in Newark forests.

Red maple trees in Newark may have an altered stomatal response (guard cell kinetics) due to lower concentrations of $\mathrm{K}+$ ions (compared to higher concentrations of $\mathrm{K}+$ in trees in Philadelphia forests) across guard cells membrane for opening the stomate aperture to regulate xylem 
transpirational pull for nutrient uptake and removal of leaf water via transpiration [37,42] in wetter, nutrient deficient soils. In Philadelphia forests, a robust ROS scavenging system of accumulated $\mathrm{K}+$ and $\mathrm{Zn} 2+$, increased free proline and other amino acids, and polyamines reported in red maples in response accumulated heavy/toxic metals (e.g., Mn, Zn, Al) were possibly compromised [14,26,49,50] in Newark forests due to limited stress regulating ions [3]. The findings of this study of lower leaf water content in red maple trees in Philadelphia forests than Newark forests suggests red maple trees in the larger city are physiologically regulated by $\mathrm{N}$-containing compounds and nutrient ions in response to cellular oxidative stress induced by complex abiotic stresses in nutrient-rich, contaminated soils that likely experience periodic water stress in warmer systems.

Larger leaf stomatal size (i.e., slower stomatal response time) and lower leaf water content observed in this study, along with greater foliar $\mathrm{K}+$ and $\mathrm{Zn} 2+$, and accumulated free amino acids (e.g., Pro, Gln, Glu, Arg) and polyamines (e.g., spermine; [3]) suggests that red maple trees have acclimated to elevated temperature, CO2, $\mathrm{N}$ deposition inputs, and accumulated heavy/toxic metals in Philadelphia forests. This acclimation was in part possible through plastic responses, such as larger stomata size that alters the stomata aperture $\mathrm{CO} 2$ concentration and transpiration gradients. In addition, larger stomata and unaffected specific leaf area suggest a greater stomata surface area-tovolume ratio for $\mathrm{CO} 2$ uptake and reduce water loss in red maple trees growing in Philadelphia forests. Red maple leaves characterized by larger stomates may be associated with slower stomatal opening due to an influx of $\mathrm{K}+$ ions especially in the guard cells (influx of $\mathrm{Ca} 2+$ ions regulate stomatal closing) for cell turgor, resulting in slower stomatal conductance rates $[37,42]$ under elevated CO2 concentrations and temperatures. Therefore, stomates are possibly partially closed most of the time under harsh conditions to conserve leaf water content (and improved iWUE) or fully open to accumulate more $\mathrm{CO} 2$ for greater productivity in red maple trees in Philadelphia forests with greater urban intensity.

Leaf morphology and anatomy response to urbanization impacts indicate plasticity of red maple trees to complex urban conditions. However, plant fitness is a cumulative response of many physiological, morphological, and biochemical adjustments [2,10,37,46,49]. McDermot et al. [3] have reported higher foliar chlorophyll, free amino acids, free spermidine, N, P, K, and Zn in red maple trees in forests across Philadelphia, PA compared to red maple trees in forests across Newark, DE. Therefore, a trend for increased stomate length and width, along with lower leaf water content, in red maple trees growing in Philadelphia forests suggest positive adaptive effects of urbanization impacts on morphology and anatomy traits likely achieved through altered soil $\mathrm{C}$ and $\mathrm{N}$ cycling and reallocation of plant $\mathrm{C}$ and $\mathrm{N}$ resources that may enhance productivity (growth and chlorophyll; [3,32]), acclimation (secondary metabolites; [3]), and survival to harsh urban conditions. In conclusion, leaf morpho-anatomy patterns and plasticity strategies indicate red maple trees may serve as a biomonitor of urban forest health and urban environmental conditions.

\section{Materials and Methods}

\subsection{Study species and geographic region}

We studied leaf morphology and anatomy of mature red maple (Acer rubrum L.) trees in six forests in the FRAME (Forest Among Managed Ecosystems) network. The FRAME traverses an urban gradient extending across Newark, DE (small city) and Philadelphia, PA (large city). Philadelphia has a population density $(4,405$ people $\mathrm{km}-2)$ three times higher and a total population $(1,526,006$ people) nearly fifty times larger than that of Newark (density =1,403 people $\mathrm{km}-2$; total population = 31,454), yet the urban intensity (e.g., impervious surface area, population density) surrounding the forest patches (within $1000 \mathrm{~m}$ of forest patch) is similar across the forests in both Newark and Philadelphia [36]. The magnitude of urban intensity at the regional scale is referred to as metro-scale impacts (proxy for urban intensity) that can stimulate growth and/or induce stress in plants in urban forests (e.g., regional urban heat island). The forest canopy of the FRAME is dominated by native tree species in both cities [36]: red maple (Acer rubrum), American beech (Fagus grandifolia), black gum (Nyssa sylvatica), sweetgum (Liquidambar styraciflua), tulip poplar (Liriodendron tulipifera), and 
red oak (Quercus rubra). The forest understory is dominated by non-native and native species: multiflora rose (Rosa multiflora), spicebush (Lindera benzoin), greenbrier (Smilax rotundifolia), Japanese honeysuckle (Lonicera japonica), southern arrowwood (Viburnum dentatum), autumn olive (Elaegnus umbellata), and sweet pepperbush (Clethra alnifolia).

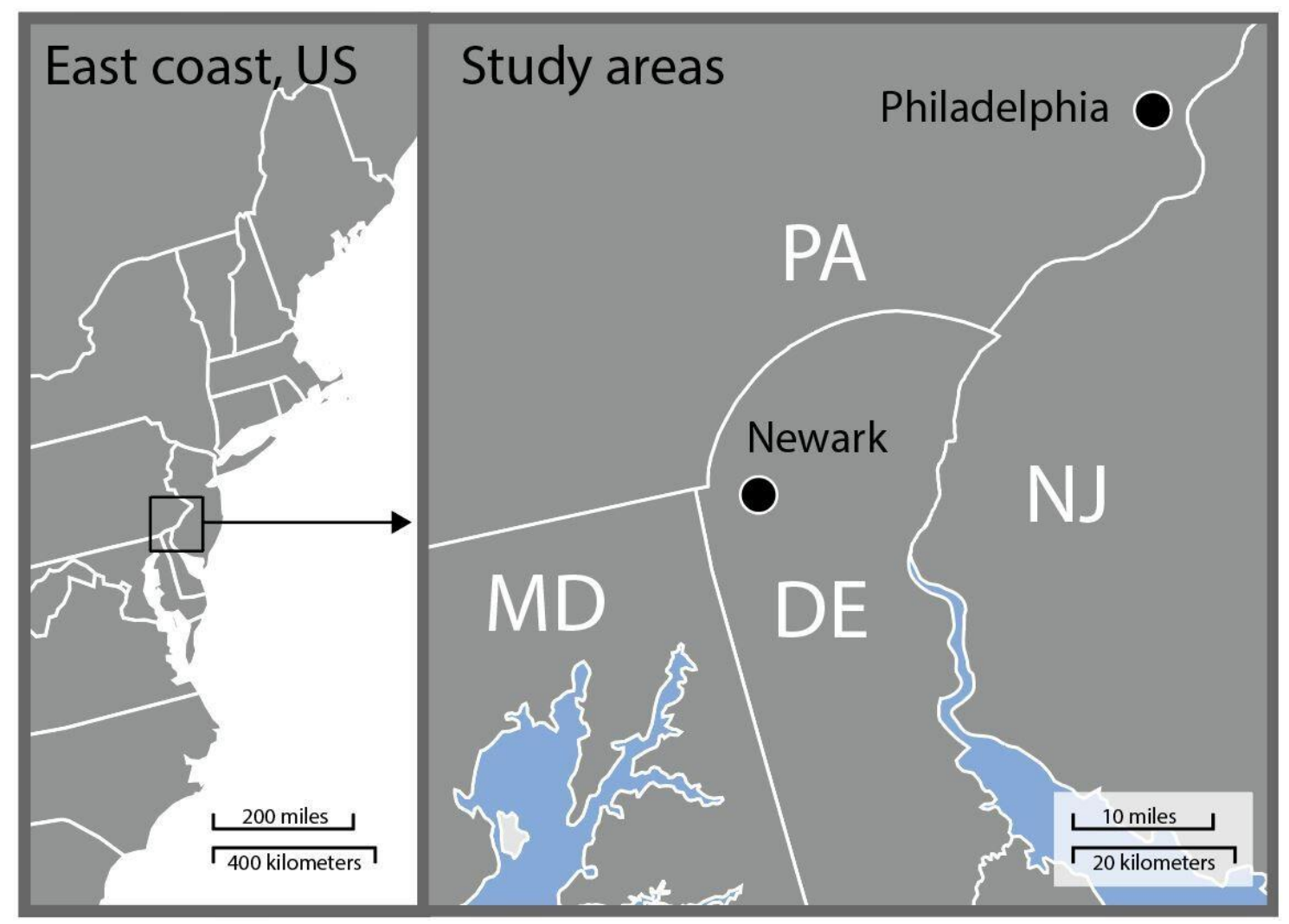

Figure 1. Map of the east coast of the U.S. showing the location of Newark, DE and Philadelphia, PA. A total of eighteen red maple trees from six forests, three forests in each city, were sampled in August 2018.

\subsection{Experimental design and tree selection,}

Three forests experiencing high levels of urbanization in Newark, DE (Ecology Woods, Chrysler Woods and Webb Farm) and in Philadelphia, PA (Chamounix, Parkline Drive and Smith Memorial) were selected for the study. Therefore, this study focused on the impacts of metro-scale urbanization pressures on leaf morphology and anatomy traits in urban trees. Three red maple trees were randomly selected in the three forests in Newark $(n=9)$ and Philadelphia $(n=9)$. Red maple tree selection details are described in McDermot et al. (in review). Leaf sampling was conducted at mid and upper canopy of red maple trees $(n=18)$ using a pole pruner or by climbing the tree in August 2018. Leaf samples were stored at $4^{\circ} \mathrm{C}$ during collection in the field prior to transport to the laboratory for leaf morphology and anatomical characterization.

\subsection{Leaf morphology trait measurements}

On fully grown leaves $(n=36)$ collected from mature red maples in Newark and Philadelphia forests, the following measurements were performed: saturated fresh leaf weight (FLW), dry leaf weight (DLW), dry leaf area (DLA), specific leaf area (SLA), leaf water content (LWC), and leaf dry matter content $($ LDMC). Fresh leaf samples $(n=180)$ were allowed to equilibrate to room temperature and FLW was recorded using a laboratory balance. Leaf samples $(n=180)$ were oven-dried at $55^{\circ} \mathrm{C}$ for $48 \mathrm{~h}$ for DLW and followed by measurements of DLA using a desktop scanner. The following calculations for leaf morphology were performed:

SLA $=$ DLA/DLW 
$\mathrm{LDMC}=\mathrm{DLW} / \mathrm{FLW}$

$\mathrm{LWC}=((\mathrm{FLW}-\mathrm{DLW}) / \mathrm{FLW}) * 100)$

\subsection{Leaf anatomy trait measurements}

Two fully healthy grown and similar size leaves from each red maple tree were punched $(\mathrm{n}=$ 36) with a $1 \mathrm{~mm} 2$ disc in locations (left or right of mid vein) that were visibly similar. Each leaf disc was added to a tray well and covered with paraformaldehyde $(0.4 \%, 1 \mathrm{~mL})$ and triton $(0.005 \%)$ for fixing cells. A polystyrene sphere was placed into each well to hold the leaf disc in place. Trays containing leaf discs were placed into a bell jar and vacuumed ( $30 \mathrm{Hg}$ pulse, $\mathrm{X} 3$ ) and stored at $4^{\circ} \mathrm{C}$ under vacuum overnight. Fixative was aspirated from leaf discs and washed three times with phosphate buffered saline (1xPBS, $1.5 \mathrm{~mL}$ ) for sectioning and staining prior to microscopic analysis. Each individual leaf disc was added to a cassette and immersed in a beaker containing 1 x PBS (50 $\mathrm{mL}$ ). Each leaf disc was processed (Leica ASP $300 \mathrm{~S}$ tissue processor) and embedded into a paraffin. The sections were cut at on a Microm HM 335E paraffin microtome. Sectioned leaf discs ( $\mathrm{n}=36 ; 5$ $\mu \mathrm{m}$; 40X objective) were stained with safranin $\mathrm{O}$ and fast green then placed between a cover glass and imaged in brightfield. Whole slide imaging was performed on the vertical section of the leaf tissue using an Aperio AT2 brightfield scanner (Leica Biosystems), and the Aperio eSlide Manager software toolkit was used to perform anatomical trait measurements of the upper epidermal thickness (UET), stomatal length (SL), stomatal width (SW), spongy mesophyll length (SML), spongy palisade length (SPL), and microscopic leaf thickness (LTm) of the leaf tissue.

For the leaf abaxial surface imaging, each leaf disc $(n=36)$ was covered with $1 \times$ PBS $(2 \mathrm{~mL})$ solution followed by the addition of calcofluor white $(1: 100,1 \%, 1 \mathrm{~mL})$ and propidium. A leaf disc was removed and placed between two pieces of cover glass. Leaf discs were imaged on the Echo Revolve microscope in the upright configuration. All images were obtained with the CFP filter. Using the $2 X$ objective and starting at the bottom right corner of the leaf disc, samples were moved 1 field of view to the left and 1 field of view up to enable unbiased analysis of stomatal density. One image was taken at the $2 X$ magnification to highlight the field of view. The objective was switched to $4 X$ and another image was obtained. The leaf disc between cover glass was inverted and the process was repeated for the other side of the leaf. Quantification of stomatal density was obtained from calculations of $4 \mathrm{X}$ images of the leaf disc abaxial surface. All quantifications were performed using the Revolve software. Three regions of interest from each image were randomly chosen for analysis.

\section{Statistical analysis}

All data analyses were conducted in R (Version 3.3.3; R Core Team, 2019). Statistical significance is reported at the $\alpha=0.10$ critical value. Analysis of differences in foliar fresh weight (FLW), dry weight (DLW), dry leaf area (DLA), specific leaf area (SLA), leaf water content (LWC), stomatal length (SL), stomatal width (SW), and upper epidermal thickness (UET) between the cities were analyzed using a one-way analysis of variance (ANOVA) for data that met the assumptions of normality and homoscedasticity. Leaf morphology and anatomy traits were analyzed using the Kruskal-Wallis nonparametric analysis of variance test when the assumptions of normality and homoscedasticity were not met.

\section{Conclusions}

Our study shows that a greater magnitude of urban pressure was associated with larger stomatal size in red maple trees in Philadelphia forests, which may lead to acclimation and prolonged tree health. In Philadelphia, increased stomate length and width in leaves of red maple trees demonstrate an acclimation response to increased nutrient loads, toxic metals, UHI, increased atmospheric CO2, and higher $\mathrm{N}$ deposition inputs. These results suggest that city size can be a proxy for evaluating different magnitudes of urbanization pressure (metro-scale impacts) on the leaf anatomy and morphology response to abiotic stresses in trees in urban landscapes. The observed acclimation in red maple trees to altered aboveground and belowground conditions, while maintaining higher 
productivity, supports the suitability of this tree species for biomonitoring urban forest health and metropolitan conditions.

Author Contributions: Conceptualization, C.M. and T.T.; Methodology, C.M. and T.T.; Software, C.M., V.D. and T.T.; Validation, C.M., V.D. and T.T.; Formal analysis, C.M. and T.T.; Investigation, C.M.; Resources, C.M. V.D. and T.T.; Data curation, C.M.; Writing- original draft, C.M.; Preparation, C.M.; Writing- review \& editing: C.M. V.D. and T.T.; Visualization, C.M. and T.T.; Supervision, T.T.; Project Administration, T.T.; Funding acquisition, V.D. and T.T.

Acknowledgments: We thank Erin Sparks and Jean Ross for internal and surface leaf image analysis, and Tim Chaya and Jeffery Chaplan for assistance with leaf sample preparation for image analysis. The authors are grateful to the undergraduate students (Mary Dineen) at UD for help with field sampling and data processing. We also thank Venessa Anderson and Kacie-Ann McDermot for help with field sampling and laboratory work. The University of Delaware Research Foundation and the USDA Forest Service (\#16-JV-11242308-122) provided funding for the research. The authors also thank the reviewers for useful suggestions for improving the manuscript.

\section{References}

1. Calfapietra, C.; Peñuelas, J.; Niinemets, Ü. Urban plant physiology: adaptation-mitigation strategies under permanent stress. Trends in Plant Science 2015, 20, 72-5.

2. Abrams, M.D. The Red Maple Paradox Bioscience 1998, 48, 355-364.

3. McDermot, C.; Minocha, R.; D'Amico, V.; Trammell, T.L.E. Red maple (Acer rubrum L.) trees demonstrate acclimation to urban conditions in temperate deciduous forests. PLoS ONE (in review).

4. Oke, T.R. City size and the urban heat island. Atmospheric Environment, 1973, 7(8), 769-779

5. Idso, C.D.; Idso, S.B.; Balling, Jr. R.C. An intensive two-week study of an urban $\mathrm{CO} 2$ dome. Atmospheric Environment 2001, 35, 995-1000.

6. Idso, S.B.; Idso, C.D.; Balling Jr. R.C. Seasonal and diurnal variations of near-surface atmospheric CO2 concentrations within a residential sector of the urban CO2 dome of Phoenix, AZ, USA. Atmospheric Environment 2002, 36, 1655-1660.

7. Lovett, G.M.; Weathers, K.C.; Sobczak, W.V. Nitrogen saturation and retention in forested watersheds of the Catskill Mountains. New York Ecological Applications 2000, 10(1), 73-84.

8. Pouyat, R.V.; Yesilonis, I.D.; Russell-Anelli, J.; Neerchal, N.K. Soil chemical and physical properties that differentiate urban land-use and cover types. Soil Sci. Soc. Am. J, 2007, 71(3), 1010-1019.

9. Royer, D.L.; McElwain, J.C.; Adams, J.M.; Wilf, P. Sensitivity of leaf size and shape to climate within Acer rubrum and Quercus kelloggii. New Phytologist 2008, 179, 808-817

10. Miller-Rushing, A.J.; Primack, R.B.; Templer, P.H.; Rathbone, S.; Mukunda, S. Long-Term relationships among atmospheric $\mathrm{CO}$, Stomata, and intrinsic water use efficiency in individual trees. American Journal of Botany 2009, 96(10), 1779-1786.

11. Pourkhabbaz, A.; Rastin, N.; Olbrich, A.; Langenfeld-Heyser, R.; Andrea, P.A. Influence of Environmental Pollution on Leaf Properties of Urban Plane Trees, Platanus orientalis L. Bull Environ Contam Toxicol 2010, 85, 251-255

12. Nowak, D.J.; Dwyer, J.F. Understanding the benefits and costs of urban forest ecosystems. In Urban and Community Forestry in the Northeast. 2nd Ed.; Kuser, J.E., ed.; Springer: Dordrecht, USA, 2007, 25-46.

13. Livesley, S.J.; McPherson, E.G.; Calfapietra, C. The Urban Forest and Ecosystem Services: Impacts on Urban Water, Heat, and Pollution Cycles at the Tree, Street, and City Scale. J. Environ. Qual, 2016, 45, 119-124.

14. Yadav, S.K. Heavy metals toxicity in plants: An overview on the role of glutathione and phytochelatins in heavy metal stress tolerance of plants. South African Journal of Botany 2010, 76, 167-179.

15. Chaturvedi, R.K.; Prasad, S.; Rana, S.; Obaidullah, S.M.; Pandey, V.; Singh, H. Effect of dust load on the leaf attributes of the tree species growing along the roadside. Environ Monit Assess 2013, 185, 383391.

16. Eisenman, T.S. Jariwala, S.P. Lovasi, G.S. (2019). "Urban trees and asthma: a call for epidemiological research". The Lancet Respiratory Medicine, 2019, 7(7), 19-20. 
17. Vos, P.E.J.; Maiheu, B.; Vankerkom, J.; Janssen, S. Improving local air quality in cities: To tree or not to tree? Environmental Pollution 2013, 183, 113-122.

18. Tong, Z.; Whitlow, T.H.; MacRae, P.F.; Landers, A.J.; Harada, Y. Quantifying the effect of vegetation on near-road air quality using brief campaigns. Environmental Pollution 2015, 201, 141-149.

19. Jahan, S.; Iqbal, M.Z. Morphological and anatomical studies of leaves of different plants affected by motor vehicles exhaust. Med J Islamic World Acad Sci 1992, 5(1), 21-23.

20. Gregg, J.W.; Jones, C.G.; Dawson, T.E. Physiological and Developmental Effects of O3 on Cottonwood Growth in Urban and Rural Sites. Ecological Applications 2006, 16(6), 2368-2381.

21. Smith et al. 2019

22. Setälä, H.; Viippola, V.; Rantalainen, A-L.; Pennanen, A.; Yli-Pelkonen, V. Does urban vegetation mitigate air pollution in northern conditions? Environmental Pollution. 2013, 183, 104-112.

23. Phillips, T.H.; Baker, M.E.; Lautar, K.; Yesilonis, I.; Pavao-Zuckerman, M.A. The capacity of urban forest patches to infiltrate stormwater is influenced by soil physical properties and soil moisture. Journal of Environmental Management 2019, 246, 11-18.

24. Pal, A.; Kulshreshtha, K.; Ahmad, K.J.; Behl, H.M. Do leaf surface characters play a role in plant resistance to auto-exhaust pollution? Flora, 2002, 197, 47-55.

25. Tomasevic', M.; Rajsic', S.; Dord-evic', D.; Tasic', M.; Krstic' J.; Novakovic', V. Heavy metals accumulation in tree leaves from urban areas. Environ Chem Lett. 2004, 2, 151-154.

26. Sharma, S.S.; Dietz, K-J. The significance of amino acids and amino acid-derived molecules in plant responses and adaptation to heavy metal stress. Journal of Experimental Botany 2006, 57(4), 711-726.

27. Whitlow, T.; Bassuk, N. Ecophysiology of urban trees and their management-The North American experience. HortScience 1998, 23, 542-546.

28. de Silva, N.D.G.; Cholewa, E.; Ryser, P. Effects of combined drought and heavy metal stresses on xylem structure and hydraulic conductivity in red maple (Acer rubrum L.). Journal of Experimental Botany, 2012, 63(16), 5957-5966.

29. Zhang, R.; Wu, J.; Li, Q.; Hänninen, H.; Peng, C.; Yao, H.; et al. Nitrogen deposition enhances photosynthesis in Moso Bamboo but increases susceptibility to other stress factors. Front. Plant Sci 2017, 8, 1975.

30. Royer, D.L.; McElwain, J.C.; Adams, J.M.; Wilf, P. Sensitivity of leaf size and shape to climate within Acer rubrum and Quercus kelloggii. New Phytologist 2008, 179, 808-817.

31. Lambrecht, S.C.; Mahieu, S.; Cheptou, P-O. Natural selection on plant physiological traits in an urban environment. Acta Oecologica 2016, 77, 67-74.

32. Sonti, N.F.; Hallett, R.A.; Griffin, K.L.; Sullivan, J.H. White oak and red maple tree ring analysis reveals enhanced productivity in urban forest patches. Forest Ecology and Management 2019, 453, 117626.

33. Little, E.L Jr. Atlas of United States trees vol. 1. conifers and important hardwoods. U.S. Dept. Agric., Forest Service 1971. Washington, D. C.

34. Townsend, A.M.; Wright, J.W.; Kwolek, W.F.; Beineke, W.F.; Lester, D.T.; Mohn, C.A.; et al. Geographic variation in young red maple grown in north central United States. Silvae Genet 1979, 28, 33-36.

35. Wiersma, G.B.; Elvir, J.A.; Eckhoff, J.D. Forest Vegetation Monitoring and Foliar Chemistry of Red Spruce and Red Maple at Acadia National Park in Maine. Environ Monit Assess 2007, 126, 27-37.

36. Trammell, T.L.E.; D’Amico, V.; Avolio, M.L.; Mitchell, J.C.; Moore, E. Temperate deciduous forests embedded across developed landscapes: younger forests harbor invasive plants and urban forests maintain native species. Journal of Ecology 2020, vol, page range.

37. Drake, P.L.; Ray, H.; Froend, R.H.; Franks, P.J. Smaller, faster stomata: scaling of stomatal size, rate of response, and stomatal conductance. Journal of Experimental Botany 2013, 64(2), 495-505.

38. Gay, A.P.; Hurd, R.G. The influence of light on stomatal density in the tomato. New Phytol. 1975, 75, $37-46$.

39. Gray, J.E.; Holroyd, G.H.; van der Lee, F.M.; Bahrami, A.R.; Sijmons, P.C.; Woodward, F.I.; et al. The HIC signaling pathway links CO2 perception to stomatal development. Nature 2000, 408, 713-716.

40. Urban, J.; Ingwers, M.; McGuire, M.A.; Teskey, R.O. Stomatal conductance increases with rising temperature. Plant Signaling \& Behavior 2017, 12(8), e1356534.

41. Purcell, C.; Batke, S.P.; Yiotis, C.; Caballero, R.; Soh, W.K.; Murray, M.; et al. Increasing stomatal conductance in response to rising atmospheric CO2. Annals of Botany, 2018, 121, 1137-1149. 
42. Lawson, T.; Blatt, M.R. Stomatal Size, Speed, and Responsiveness Impact on Photosynthesis and Water Use Efficiency1[C]. Plant Physiology 2014, 164, 1556-1570.

43. Wang, W.; Zheng, Q; Shen, Q.; Guo, S. The Critical Role of Potassium in Plant Stress Response. Int. J. Mol. Sci 2013, 14, 7370-7390.

44. Egilla, J.N.; Davies Jr., F.T.; Boutton, T.W. Drought stress influences leaf water content, photosynthesis, and water-use efficiency of Hibiscus rosa-sinensis at three potassium concentrations. Photosynthetica 2005, 43(1), 135-140.

45. Flexas, J.; Ribas-Carbó, M.; Bota, J.; Galmés, J.; Henkle, M.; Martínez-Cañellas, S.; et al. Decreased Rubisco activity during water stress is not induced by decreased relative water content but related to conditions of low stomatal conductance and chloroplast CO2 concentration. New Phytologist 2006a, 172, 73-82.

46. Hu, B.; Simon, J.; Günthardt-Goerg, M.S.; Arend, M.; Kuster, T.M.; Rennenberg, H. Changes in the dynamics of foliar $\mathrm{N}$ metabolites in oak saplings by drought and air warming depend on species and soil Type. PLoS ONE 2015, 10(5), e0126701.

47. Winter, G.; Todd, C.D.; Trovato, M.; Forlani, G.; Funck, D. Physiological implications of arginine metabolism in plants. Front. Plant Sci. 2015, 6, 534.

48. Zhang, D.; Li, H.; Xu, H.; Zhang, W.; Shi, X.; et al. An Arabidopsis Zinc Finger Protein increases abiotic stress tolerance by regulating sodium and potassium homeostasis, reactive oxygen species scavenging and osmotic potential. Front. Plant Sci. 2016, 24.

49. Minocha, R.; Shortle, W.C.; Lawrence, G.B.; David, M.B.; Minocha, S.C. Relationships among foliar chemistry, foliar polyamines, and soil chemistry in red spruce trees growing across the northeastern United States. Plant Soil 1997, 19(1), 109-122.

50. Mohasseli, V.; Khoshgoftarmanesh, A.H.; Shariatmadari, H. The Effect of Air Pollution on Leaf Iron (Fe) Concentration and Activity of Fe-Dependent Antioxidant Enzymes in Maple. Water Air Soil Pollut 2016, 227, 3-12. 